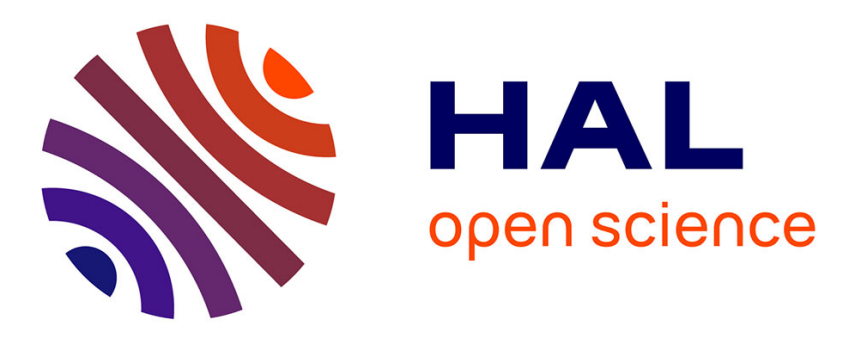

\title{
Estimating crop pollinator population using mark-recapture method
}

Marcela Yamamoto, Camila Junqueira, Ana Barbosa, Solange Augusto, Paulo Oliveira

\section{- To cite this version:}

Marcela Yamamoto, Camila Junqueira, Ana Barbosa, Solange Augusto, Paulo Oliveira. Estimating crop pollinator population using mark-recapture method. Apidologie, 2014, 45 (2), pp.205-214. 10.1007/s13592-013-0238-1 . hal-01234715

\section{HAL Id: hal-01234715 https://hal.science/hal-01234715}

Submitted on 27 Nov 2015

HAL is a multi-disciplinary open access archive for the deposit and dissemination of scientific research documents, whether they are published or not. The documents may come from teaching and research institutions in France or abroad, or from public or private research centers.
L'archive ouverte pluridisciplinaire HAL, est destinée au dépôt et à la diffusion de documents scientifiques de niveau recherche, publiés ou non, émanant des établissements d'enseignement et de recherche français ou étrangers, des laboratoires publics ou privés. 


\title{
Estimating crop pollinator population using mark-recapture method
}

\author{
Marcela YAmамото ${ }^{1}$, Camila Nonato Junqueira ${ }^{2}$, Ana Angélica Almeida Barbosa ${ }^{2}$, \\ Solange Cristina Augusto ${ }^{2}$, Paulo Eugênio Oliveira ${ }^{2}$ \\ ${ }^{1}$ Departamento de Biologia, Universidade Estadual de Goiás, Unidade Universitária de Quirinópolis, Avenida Brasil \\ Quadra 03 Lote 01 Conjunto Hélio Leão III, 75860-000 Quirinópolis, Goiás, Brazil \\ ${ }^{2}$ Programa de Pós-Graduação em Ecologia e Conservação de Recursos Naturais, Instituto de Biologia, Universidade \\ Federal de Uberlândia, Campus Umuarama, 38400-902 Uberlândia, MG, Brazil
}

Received 23 March 2013 - Revised 7 August 2013 - Accepted 3 September 2013

\begin{abstract}
Xylocopa species are large solitary bees, which are effective pollinators of yellow passion fruit, a self-incompatible crop dependent on pollination for fruit production and economic viability. We tested the mark-recapture method to estimate these bees' population size in a passion fruit commercial orchard in Central Brazil. We collected data during 3 years and population was estimated as 118, 339, and 1,032 individuals. Population size and abundance of Xylocopa bees were higher in the last studied year. These bees maintained $32.5 \%$ of natural fruit set, above economic viability levels, and higher than other commercial orchards, although population size showed no direct correlation with natural fruit set. Improvement of nesting site may explain population increase, reinforcing the importance of management. Our results showed that the markrecapture technique can provide reliable estimates of Xylocopa bees population size and, thus, be useful in monitoring population trends.
\end{abstract}

\section{Brazilian savanna / carpenter bee / Jolly-Seber method / Passiflora edulis f. flavicarpa / Xylocopa}

\section{INTRODUCTION}

Mark-recapture methods are often used to estimate population size based on a single source of individual identification such as natural markings or artificial tags (Krebs 1989). There are classic mark-recapture methods for large animals as ear tags for mammals and colour bands for birds, for example (Lettink and Armstrong 2003). However, there are no standardized methods for small animals such as insects to estimate and monitor population trends, except for some groups like

Corresponding author: P. E. Oliveira, poliveira@ufu.br

Manuscript editor: Klaus Hartfelder butterflies (e.g. Haddad et al. 2008) and some Orthoptera species (e.g. Jamieson et al. 2000).

For wild bees, the population size has been estimated in experimental studies, as to monitor Osmia rufa in trap-nests (Steffan-Dewenter and Schiele 2004), or in natural populations for those species with some special features such as aggregation of nests, as in Andrena vaga bees, which emerge in a particular time and occupy specific places around their nests (Bischoff 2003). There are studies also involving an oligolectic bee, A. hattorfiana, sampled during flowering season associated to Knautia arvensis (Dipsacaceae) plants (Larsson and Franzén 2008). However, no mark-recapture method study has been used to estimate the population size of non-social bees that pollinate crops. Actually, information about solitary bee popula- 
tions is limited because nest sites are inconspicuous, some species have very small populations, and quantitative data on density and dispersal are difficult to obtain (Michener 2000).

Solitary bees and wild bee as a whole provide an important ecosystem service promoting pollen flow in natural areas and improving crop production. In face of the concerns about pollinators decline (e.g. National Research Council of the National Academies 2007; Potts et al. 2010), some aspects of pollinators biology need to be considered to management and conservation guidelines. These points are highlighted in the protocol to assess the pollination deficit in crop (Vaissière et al. 2011), and the lack of knowledge on these issues has been identified as an impediment on this direction. The size of pollinator population can offer some important information concerning crop pollination since population density is strictly associated to visitation and seed or fruit production (Kunin 1997).

We used the Xylocopa bees as a model to estimate the population size of a crop pollinator using mark-recapture method. These large solitary bees were considered the effective pollinator of yellow passion fruit, a self-incompatible crop widely cultivated in Brazil. Passion fruits are consumed fresh or used in the juice industry and have been important to the development of sustainable farming systems in the Cerrado, the savanna region in Central Brazil. The Cerrado is one of the most threatened biomes of South America because of the rapid expansion of cash crop agriculture (Klink and Moreira 2002), one of the 25 world conservation hotspots due to rapid loss of biodiversity (Myers et al. 2000). In Triângulo Mineiro region, Cerrado area is under heavy human pressure (Cavalcanti and Joly 2002). In this area, passion fruit production rely on four large species of Xylocopa (Yamamoto et al. 2012) but sustainable pollination and production may be hindered by those bees dwindle populations (Camillo 2003).

Previous estimates pointed out that depending on the species of bee pollinator, around 350-1,000 individuals are needed to efficiently pollinate 1.0 ha of yellow passion fruit orchard (Kavati 1998). Other estimates, considering only Xylocopa species indicate that 300-350 females are required to pollinate 1.0 ha orchard with $12,000-14,000$ flowers (Melo et al. 2005). Therefore, our objective was to use multiple mark-recapture technique to estimate population size of Xylocopa species during the yellow passion fruit flowering season, and relate this information with fruit production and economic viability.

\section{MATERIAL AND METHODS}

\subsection{Study site}

We conducted the study at Água Limpa Farm, Experimental Station of Universidade Federal de Uberlândia $\left(1^{\circ} 05^{\prime} 22^{\prime \prime} \mathrm{S}, 48^{\circ} 21^{\prime} 15^{\prime \prime} \mathrm{W}\right)$. The farm has 104 ha of preserved area and 43 ha of orchards with a variety of fruit crops including a 0.5 ha yellow passion fruit orchard (Neto 2008). Xylocopa (Neoxylocopa) frontalis (Olivier, 1789), Xylocopa (Neoxylocopa) suspecta Moure and Camargo, 1988, Xylocopa (Neoxylocopa) grisescens Lepeletier, 1841, and Xylocopa (Neoxylocopa) hirsutissima Maidl, 1912 were the main passion fruit pollinators (Yamamoto et al. 2012). This area was used to study trap-nesting occupation by Xylocopa species during the years 2006 and 2007, with availability of 80 trap-nests (Mesquita and Augusto 2011), and a long-term trap-nesting experiment focused on $X$. frontalis and $X$. grisescens was carried out from 2008 to 2011 using 384 trap-nests (Junqueira et al. 2012). There is a marked difference between seasons in the region: a warmer rainy season from October to March, and a cooler and almost rainless dry season from April to September. The average monthly temperatures ranged from 18 to $24{ }^{\circ} \mathrm{C}$ and annual rainfall varied from 1,300 to $1,700 \mathrm{~mm}$ (Rosa et al. 1991).

\subsection{Biology of Xylocopa species}

Xylocopa bees are wood-nesting generalist pollinators of broad geographical distribution (Hurd 1978). The genus comprises about 730 species around world (Gerling et al. 1989), and 50 species are described in Brazil (Silveira et al. 2002). These bees mostly burrow nests in dead or decaying wood (Silveira et al. 2002). Females may also use pre-existing cavities such as floral stalks (Ramalho et al. 2004), and trap-nests such as wood logs or planks (Freitas and Oliveira-Filho 2001; Camillo 
2003; Oliveira-Filho and Freitas 2003; Chaves-Alves et al. 2011) or bamboo canes (Chaves-Alves et al. 2011; Pereira and Garófalo 2010, Junqueira et al. 2012).

The life cycle of Xylocopa bees from egg to adult varies among species, and to $X$. grisescens, $X$. frontalis, and $X$. suspecta ranges from 45 to 65 days (Camillo and Garófalo 1982; Camillo et al. 1986). The longevity of females also varies widely and may be only few months to a year (O'toole and Raw 1991; Pereira and Garófalo 2010; Junqueira et al. 2012). These species present multivoltinism and produce more than one generation per year (Camillo and Garófalo 1989). Nesting occurs throughout the year with higher frequencies from December to March and from July to September (Camillo 2003). Nest foundation is solitary but nest reuse is frequent, maintaining these nests active for several months (Camillo 2003; Chaves-Alves et al. 2011). Usually there is a single mature female per nest, or at most two females (Camillo and Garófalo 1989). Foraging activities to collect larval food (pollen and nectar) occur throughout the day (Camillo and Garófalo 1982; 1989). Although bees differed a bit in size and are relatively easy to identify in the field, they use a similar guild of flowers and are important pollinators of passion fruit (Yamamoto et al. 2012).

\subsection{Mark-recapture}

We collected data on rainless days during the flowering period of yellow passion fruit in a 0.5 -ha orchard. Sampling sessions were carried out during three different years in 2005 (29 March to 01 April, $n=4$ days), 2007 (22 to 26 January, $n=5$ days), and 2011 (01 to 08 February, $n=6$ days) with similar sample effort between years. In 2005, there was no availability of trap-nest substrate for Xylocopa, whilst in 2007 and 2011 there were trap-nests available for the bees around the orchard. The flowering period of yellow passion fruit occurs during the warm rainy period, showing 7-10 days peaks of high flower production scattered along the blooming period and followed by 45-50 days with a few or no flowers (Silva 2005). The weather conditions during marking sessions were similar: sunny days with temperature around $29.6^{\circ}$ $\mathrm{C} \pm 2.62^{\circ} \mathrm{C}$ and $52.4 \% \pm 8.43 \%$ of humidity. We captured bees over 2-4 h per day (two collectors and at least an experienced one) with insect nets walking along the orchard lines when bees were visiting flowers.

After net-collection, we put the bees in a modified plastic syringe to position and marking them (Figure 1a, $\mathrm{b}, \mathrm{c}$ ). We attached a numbered $2 \mathrm{~mm} \times 2 \mathrm{~mm}$ tag on the mesothorax of bees with cyanoacrylate adhesive (Figure 1b, d). The tag had an individual alphanumeric combination printed on inkjet photo paper and was previously covered with polyvinyl chloride waterproof varnish. After the glue was dry, the marked individuals were released apparently unharmed (Figure 1e). This marking allowed identifying the bee individually in the field and thereby estimate the abundance of pollinators. Recaptured individuals had their number recorded and were released as soon as possible. We considered the abundance of pollinators as the number of marked individuals plus recaptured individuals per day. Individuals recaptured more than once a day were counted only once.

We estimated the population size of pollinators with Jolly-Seber method recommended for open population with several occasions to mark and recapture, using the Ecological Methodology program version 7.0 (Krebs 1989). The method depends on marking a reasonable number of individuals and obtaining recaptures at all times (Krebs 1989). We used one-way ANOVA to compare the abundance of pollinators among years, additionally we used Tukey's HSD test for postANOVA pair wise comparisons. The abundance of pollinators had a non-normal distribution, so we logtransformed data before statistical analyses. Due to small sample sizes, we used $\chi^{2}$ test to compare mean population size of pollinators along years $(2005,2007$, and 2011), and to compare the proportion of recaptured bees among years.

\subsection{Pollination tests}

To analyze the correlation between the abundance of individuals and the population size of Xylocopa with natural fruit set of passion fruit we tagged some flowers daily during the same days of mark-recapture experiments in 2007 and 2011. After 15 days, we checked fruit production. To include 2005 data, we used monthly data of natural fruit set for the same area using the same methodology but not exactly in the same days of mark-recapture experiments (Yamamoto et al. 2012). We used $\chi^{2}$ test to compare natural fruit 

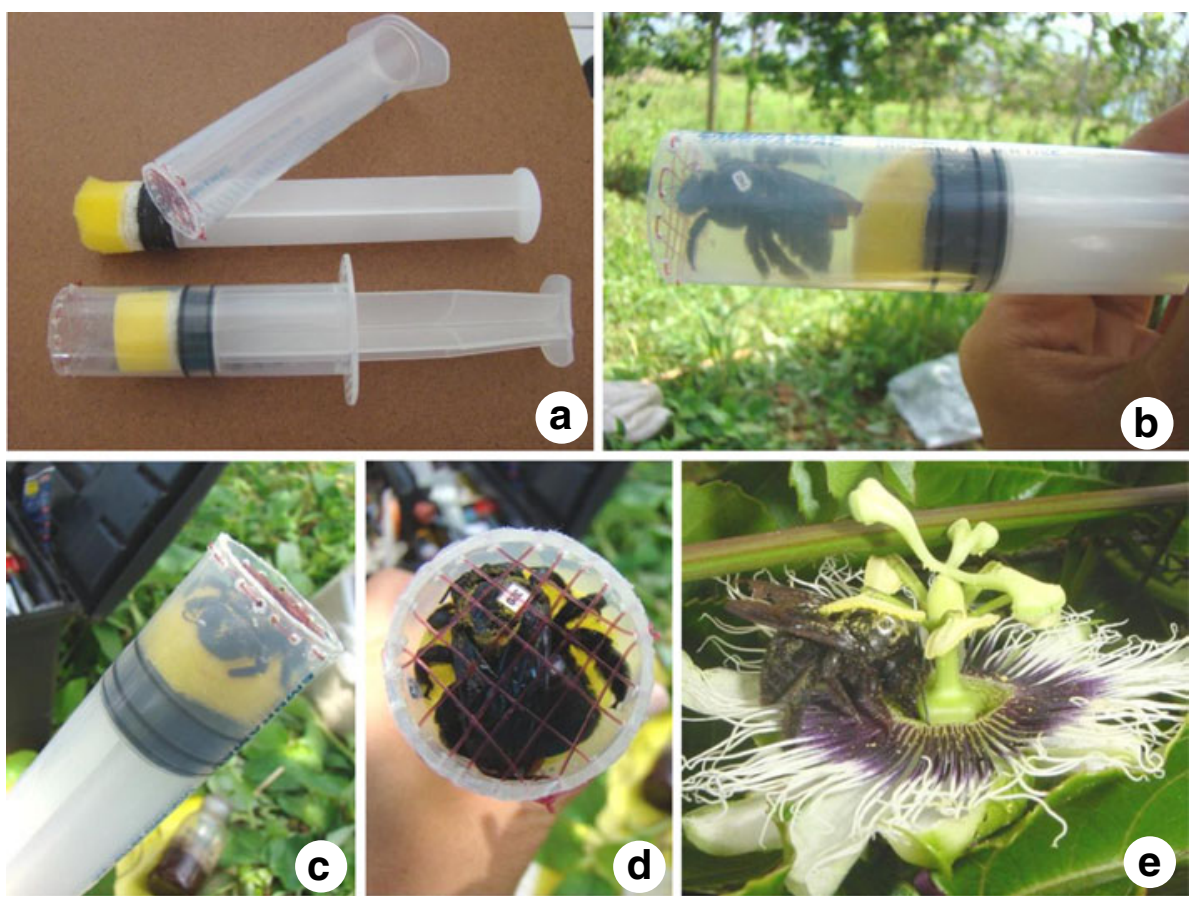

Figure 1. Marking of Xylocopa bees using a numbered tag a detail of modified syringe, $\mathbf{b}$ bee inside the syringe, $\mathbf{c}$ and $\mathbf{d}$ positioning of the bee on the syringe, and $\mathbf{e}$ a marked individual visiting yellow passion fruit flower

set among years. We analysed the correlation between the natural fruit set of passion fruit with the abundance of pollinators and pollinator population size using Pearson test with Bonferroni correction and logtransformed data. In 2011, the yellow passion fruit orchard was destroyed by Fusarium wilt, a disease favoured by high temperature and humidity (Liberato and Costa 2001). Many plants maintained flowers allowing bee capture and flower marking for fruit set. However, most of these plants died afterwards, possibly affecting the results of the pollination tests done during this period.

\section{RESULTS}

\subsection{Population estimate}

The abundance of Xylocopa bees had the same sample effort among species. Our data showed the abundance of $X$. frontalis and $X$. suspecta during sampled periods was always above 38 individuals reaching almost 160 marked bees per year. In contrast, $X$. grisescens and $X$. hirsutissima were less abundant with no more than 10 individuals per year (Table I). Therefore, data from $X$. grisescens and $X$. hirsutissima did not allow some specific analyses.

The abundance of all marked Xylocopa bees collected on the passion fruit flowers was different among years $\left(F_{(2 ; 12)}=9.82, P=0.003\right)$ and the same was observed for $X$. frontalis and $X$. suspecta in separate $\left(F_{(2 ; 12)}=8.98, P=0.004\right.$ and $F_{(2 ; 12)}=10.06, P=0.003$, respectively). The posthoc test indicated significantly higher abundance in the last year (Figures 2 and $3 a, b)$.

Collected data (detailed in Table I) allowed to estimate the population size of Xylocopa bees as a whole for all years and to $X$. frontalis in separate in 2007 and 2011. Data for the other species did not allow such estimate. Although $X$. suspecta was as abundant as $X$. frontalis, the irregular recapture of individuals did not allow any estimates. $X$. hirsutissima and $X$. grisescens had much lower abundance of both marked and recaptured indi- 
Table I. Sums of captured individuals $\left(\Sigma n_{i}\right)$ and recaptured individuals $\left(\Sigma m_{i}\right)$ with the proportion of marked individuals recaptured by species in parenthesis, number of sampled periods $(k)$, marked proportion $(\alpha \pm \mathrm{SD})$, probability of survival $(\varphi \pm \mathrm{SD})$, and estimated population size $\left(\Sigma B_{i} \pm \mathrm{SD}\right)$ of yellow passion fruit pollinators for each year

\begin{tabular}{llllllll}
\hline Years & Species & $\Sigma n_{i}$ & $\Sigma m i$ & $k$ & $\alpha$ & $\varphi$ & $\Sigma B i$ \\
\hline 2005 & X fro & 59 & $3(5.1 \%)$ & 4 & - & - & - \\
& X gri & 10 & $2(20 \%)$ & 4 & - & - & - \\
& X sus & 38 & $3(7.9 \%)$ & 4 & - & - & - \\
& Total & 107 & $8(7.5 \%)$ & 4 & $0.13 \pm 0.08$ & $0.44 \pm 0.47$ & $118 \pm 8.06$ \\
2007 & X fro & 40 & $11(27.5 \%)$ & 5 & $0.31 \pm 0.16$ & $1.13 \pm 0.62$ & $67 \pm 42.58$ \\
& X gri & 6 & $2(33.3 \%)$ & 5 & - & - & - \\
& X hir & 3 & 0 & 5 & - & - & - \\
& X sus & 56 & $4(7.1 \%)$ & 5 & - & - & $339 \pm 360.29$ \\
& Total & 105 & $17(16.2 \%)$ & 5 & $0.20 \pm 0.11$ & $1.15 \pm 0.66$ & $436 \pm 447.99$ \\
& X fro & 142 & $55(38.7 \%)$ & 6 & $0.23 \pm 0.13$ & $1.65 \pm 1.87$ & - \\
& X gri & 9 & $3(33.3 \%)$ & 6 & - & - & - \\
& X hir & 1 & $1(100 \%)$ & 6 & - & - & $1,032 \pm 690.11$ \\
& X sus & 158 & $18(11.4 \%)$ & 6 & - & - & \\
& Total & 310 & $77(24.8 \%)$ & 6 & $0.22 \pm 0.07$ & $2.40 \pm 2.84$ & \\
\hline
\end{tabular}

X fro Xylocopa frontalis, $X$ gri X. grisescens, $X$ sus X. suspecta, $X$ hir X. hirsutissima

viduals. The estimated population size of Xylocopa bees as a whole was 118, 339, and 1,032 individuals for the 0.5 ha orchard during the study period (236, 678, and 2,064 individuals/ha/year). Both $X y$ locopa bees population as a whole and $X$. frontalis in separate showed significant differences among years $\left(\chi^{2}=703.03, d f=6, P<0.001 ; \chi^{2}=\right.$ 29.86, $d f=3, P<0.001$, respectively).

The marked proportion of bees seemed to be similar among years whereas the probability of survival increased (Table I). We observed that the proportion of recaptured individuals for all $X y l o c o p a$ bees increased over the years (Table I) $\left(\chi^{2}=9.26, d f=2, P<0.001\right)$, as also found for $X$. frontalis $\left(\chi^{2}=24.63, d f=2, P<0.001\right)$. The recapture for $X$. suspecta and $X$. grisescens was not different among years $\left(\chi^{2}=1.19, d f=2, P<0.552\right.$; $\chi^{2}=4.08, d f=2, P=0.129$, respectively).

Around $12.1 \%$ of marked individuals were recaptured only once, $1.0 \%$ twice, $1.5 \%$ three times, and $1.5 \%$ four times. Furthermore, on the last day of each data collection, we still observed unmarked individuals. During all mark-recapture periods we marked only two male individuals in 2011.

\subsection{Pollination tests}

The natural fruit set ranged from 25.7 to $38.7 \%$ during studied period (Table II), with no significant difference among years $\left(\chi^{2}=2.71, d f=2, P=0.258\right)$. We found no significant correlation between natural fruit set neither with the abundance of Xylocopa bees (Pearson coefficient $r=-0.31, P=0.32$ and $r=-0.07, P=0.88$ without 2005 fruit set data) nor with estimated population size $(r=0.28, P=0.55$ and $r=0.28, P=0.54$ without 2005 fruit set data).

\section{DISCUSSION}

As far as we know, this was the first study to estimate population size of solitary bees in a crop 


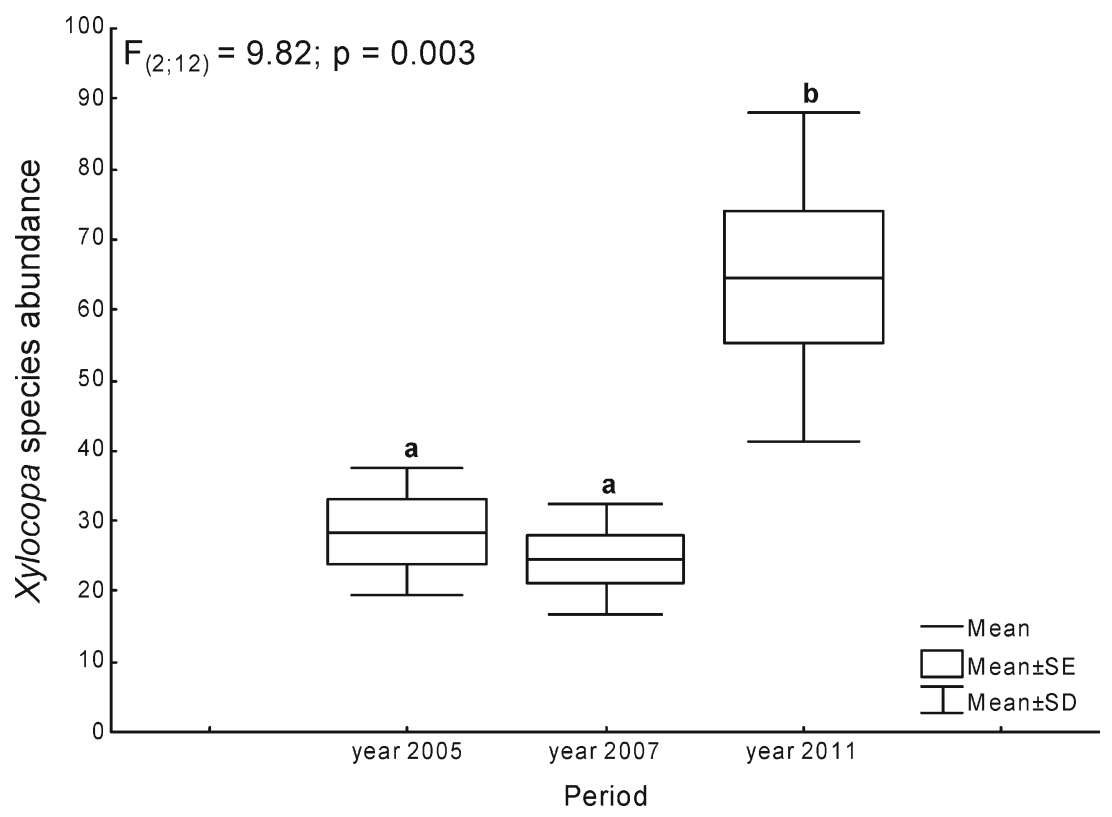

Figure 2. Abundance of Xylocopa bees had significant difference $\left(F_{(2 ; 12)}=9.82, P=0.003\right)$ among years. Different letters indicate statistically significant differences according to one-way ANOVA followed by Tukey's test $(P<0.05)$

area, using the multiple mark-recaptures method. Our study model seemed to have succeeded in estimating the population size for the Xylocopa species visiting the yellow passion fruit orchard over the years, although success differed between bee species. Moreover, our findings pointed to an increment of the number of Xylocopa bees as a whole from a few hundred to a thousand individuals, probably driven by the availability of nesting places provided by the trap-nest experiments, which reinforces the importance of management to maintain sustainable pollination by native solitary bees.

Although the Jolly-Seber method requires a large sampling effort to obtain good results, we were able to estimate the population size of pollinators for the three study years. Some parameters contributed to apply the mark-recapture method in our model, such as the abundance of individuals in the area, the catchability of Xylocopa bees associated to the attractivity of passion fruit flowers. We tagged all species of $X y l o c o p a$ recorded in region and $X$. frontalis and $X$. suspecta were the most abundant in the passion fruit orchard, which corroborates results of higher frequency of visits of these bees observed on passion fruit flowers (Yamamoto et al. 2012). $X$. frontalis was also the most frequent in trap-nests around the area (Chaves-Alves et al. 2011; Junqueira et al. 2012).

Although it was possible to estimate population size per species only for $X$. frontalis, we may suppose that $X$. suspecta population could be equally larger, but the problem was that the individuals of this species were not recaptured enough to apply the estimation method. Our data showed that $X$. suspecta contributed with 35.5 and $53.3 \%$ of all marked individuals during the study period, but their recapture was not superior to $11.4 \%$ (Table I). In contrast, we were able to estimate $X$. frontalis population size whenever we recaptured at least $27 \%$ of marked individuals. Considering bee population, the method of markrecapture seems to be more accurate when the number of sampling periods and the capture probability are high (Bischoff 2003). The Ecological Methodology software (Krebs 1989) we used requires recaptures at all times in order to produce population estimates.

Our data showed that Xylocopa species had the same proportion of recaptured individuals between 

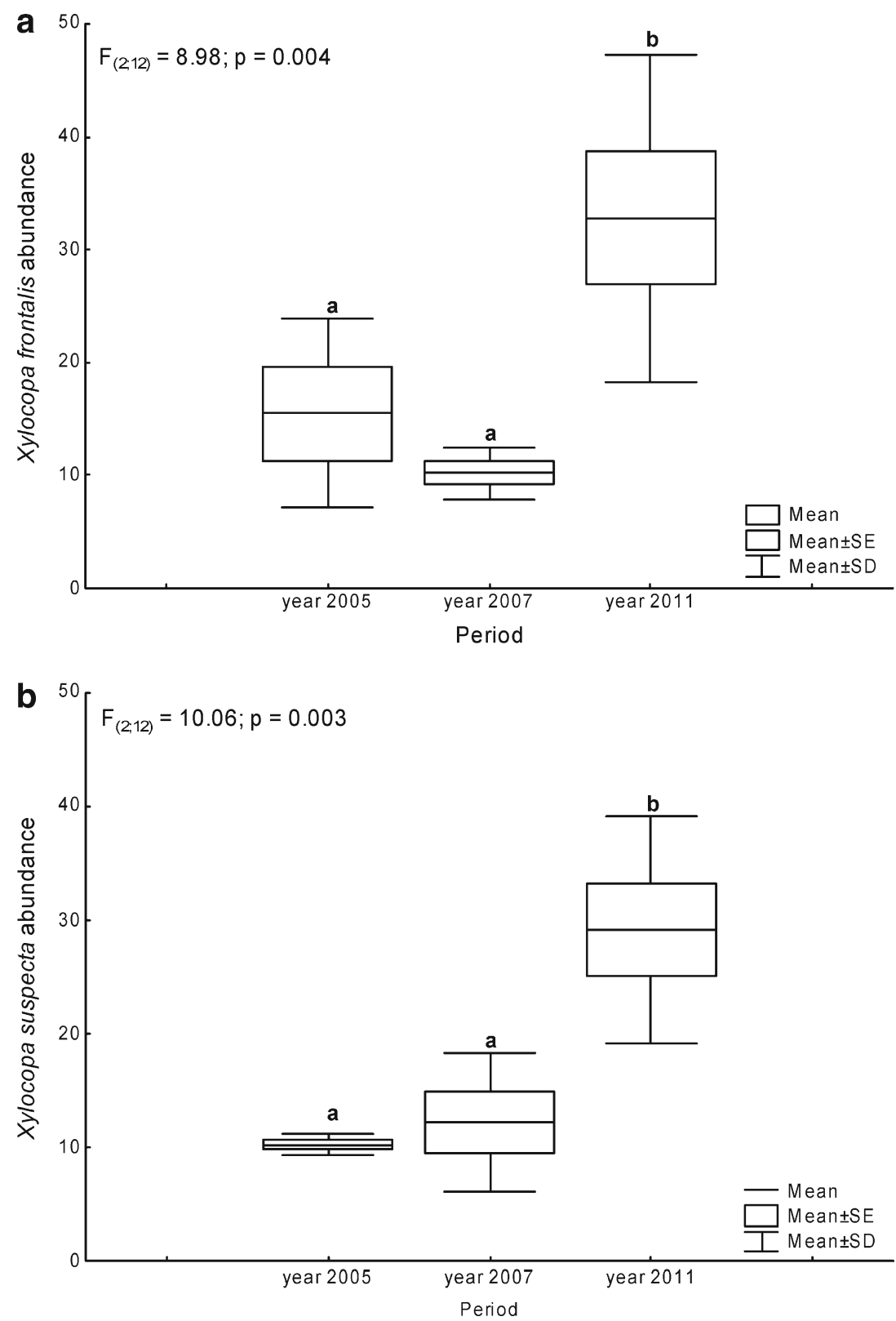

Figure 3. a Abundance of $X$. frontalis had significant difference $\left(F_{(2 ; 12)}=8.98, P=0.004\right)$ among years as observed to $\mathbf{b}$ abundance of $X$. suspecta $\left(F_{(2 ; 12)}=10.06, P=0.003\right)$. Different letters indicate statistically significant differences according to one-way ANOVA followed by Tukey's test $(P<0.05)$

years as expected by the method, except for $X$. frontalis. An explanation for the increased recapture of $X$. frontalis may be the trap-nest experiments near the orchard. The experimental trap- nests were mostly used by $X$. frontalis $(57.6 \%)$, less by $X$. grisescens $(39.0 \%)$, and only by two individuals of $X$. suspecta (3.4\%) (Junqueira et al. 2012). Apparently, X. suspecta prefers other 
Table II. Natural fruit set of yellow passion fruit in a Central Brazil orchard

\begin{tabular}{lcc}
\hline Years & Mean of fruit set \pm SD $(\%)$ & Number of flowers \\
\hline 2005 & $30.7 \pm 10.75$ & 60 \\
2007 & $38.7 \pm 16.12$ & 150 \\
2011 & $25.7 \pm 12.30$ & 130 \\
\hline
\end{tabular}

substrates to nest instead of bamboo canes offered as trap-nests (Chaves-Alves et al. 2011). Since bees are limited to a certain foraging area within the flight range from the nest (Larsson and Franzén 2008), trap-nest using may explain the more regular and increasing visits of $X$. frontalis on passion fruit flowers. Similarly, it is conceivable that the majority of marked $X$. suspecta individuals came from the native areas surrounding the orchard, which would explain irregular visitation and recapture of individuals.

It is worth of note, however, that the increase in population size of Xylocopa bees also indicates reliable food resources surrounding the yellow passion fruit orchard. Since the studied site has 104 ha of preserved area (Neto 2008), available flower resources can maintain pollinator bees and nesting sites provided by trap-nests may sustain local pollination services. A recent review showed evidence that the availability of food resources directly regulates bee populations, with less clear evidence that other direct factors as nesting resources and incidental risks may be limiting (Roulston and Goodell 2011).

Our results indicated that the estimated Xylocopa population in the studied yellow passion fruit orchard varied from a few hundred bees to more than a thousand individuals over the three years study, probably due to nest site improvement. These pollinators helped to maintain around $32.5 \%$ of natural fruit set at studied area, a much higher value than that considered as required for economic viability in the region (above $20 \%$ according to Silva 2005), and higher percentage than that found in other places in Brazil, e.g. $3.27 \%$ in São Paulo State (Camillo 2003), and $9.4 \%$ in Bahia State (Siqueira et al. 2009). The negative effects of the Fusarium disease in 2011 on fruit production probably hindered any correlation between pollinator's population size and fruit set during the study. But density of Xylocopa bees in the area, both estimated here and actually censed in the same orchard (Junqueira et al. 2012), indicated pollination and fruiting success without the plague would have been greater in 2011. Other results pointed that species richness of pollinators and their frequency were positively associated with reproductive efficacy of passion fruit in orchards in Central Brazil (Yamamoto et al. 2012).

Considering that our method addressed effective pollinators only, the population size estimated (236, 678 , and 2,064 individuals/ha/year) was near or much higher than the expected range (300-350 individuals) to efficiently pollinate a passion fruit orchard (Kavati 1998; Melo et al. 2005). The abundance or diversity of bees in a local area may be related to the type, amount, or connectivity of surrounding natural areas (Roulston and Goodell 2011) and farmers may carry out activities of maintenance and management to ensure the presence of bees. In this sense, mark-recapture procedures can be a quick and reliable method to evaluate these actions, estimate bee density and foresee economic viability of passion fruit orchards. Despite differences in recapture rates among bee species, the low cost of marking procedures indicates this method may be used more widely with tropical solitary bees, both to estimate minimum population size for sustainable use and economic viability of bee pollination, and to detect population changes associated to management.

\section{ACKNOWLEDGMENTS}

We are thankful to J.C. Santos for valuable suggestions, to P.E.F Alvarenga, T.M. Chaves-Alves, H.L. Pedroso, and O.H.P. Armondes for help in data collection. Thanks are also due to R.F. Freitas, C.T. Santos, G.R.O. Freitas; H. Grande; J.Z. Júnior; M.R. Tavares; N.G. Bordon; N.A.S. Filho; R.A.S. Molina for helping us in field activities in 2007. Financial support came from PROBIO/Pollinator/Brazil Environment Ministry (Grant 
0112-00/2005), and FAPEMIG-Research Support Foundation of Minas Gerais (Grants CRA-2037/05, APQ-01755/2009, and grants for the first author CRAPDJ 0187/09 and CRA-BPD 0132-11).

Estimation de la population de pollinisateurs de fruits de la passion par l'utilisation de la méthode de capturerecapture

Savanne brésilienne / abeille charpentière / méthode de Jolly-Seber / Passiflora edulis f. flavicarpa / Xylocopa

Schätzung der Bestäuberpopulation für Passionsfrucht mittels einer Markierungs-Wiederfang-Methode

\section{Brasilianische Savanne / Jolly-Seber Methode / Passiflora edulis f. flavicarpa / Xylocopa}

\section{REFERENCES}

Bischoff, I. (2003) Population dynamics of the solitary digger bee Andrena vaga Panzer (Hymenoptera, Andrenidae) studied using mark-recapture and nest counts. Popul. Ecol. 45(3), 197-204

Camillo, E. (2003) Polinização de maracujá. Holos Editora, Ribeirão Preto

Camillo, E., Garófalo, C.A. (1982) On the bionomics of Xylocopa frontalis (Oliver) and Xylocopa grisescens (Lepeletier) in Southern Brazil. I-Nest construction and biological cycle. Rev. Bras. Biol. 42(3), 571582

Camillo, E., Garófalo, C.A. (1989) Social organization in reactivated nests of three species of Xylocopa (Hymenoptera, Anthophoridae) in southeastern Brasil. Insect. Soc. 36(2), 92-105

Camillo, E., Garófalo, C.A., Muccillo, G. (1986) On the bionomics of Xylocopa suspecta (Moure) in Southern Brazil: nest construction and biological cycle (Hymenoptera, Anthophoridae). Rev. Bras. Biol. 46(2), 383-393

Cavalcanti, R.B., Joly, A.C. (2002) Biodiversity and conservation priorities in the Cerrado region. In: Oliveira, P.S., Marquis, R.J. (eds.) The Cerrados of Brazil: ecology and natural history of a neotropical savanna, pp. 351-367. Columbia University Press, New York

Chaves-Alves, T.M., Junqueira, C.N., Rabelo, L.S., Oliveira, P.E.A.M., Augusto, S.C. (2011) Recursos ecologicos utilizados por las especies de Xylocopa (Hymenoptera, Apidae) en el área urbana. Rev. Colomb. Entomol. 37(2), 313-317

Freitas, B.M., Oliveira-Filho, J.H. (2001) Criação racional de mamangavas para polinização em áreas agrícolas. Banco do Nordeste, Fortaleza
Gerling, D., Velthuis, H.H.W., Hefetz, A. (1989) Bionomics of the large carpenter bees of the genus Xylocopa. Annu. Rev. Entomol. 34, 163-190

Haddad, N.M., Hudgens, B., Damiani, C., Gross, K., Kuefler, D., Pollock, K. (2008) Determining optimal population monitoring for rare butterflies. Conserv. Biol. 22(4), 929-940

Hurd, P.J. (1978) An annotated catalog of the carpenter bees (Genus Xylocopa) of the Western Hemisphere (Hymenoptera: Anthophoridae). Smithsonian Institution Press, Washington

Jamieson, I.J., Forbes, M.R., McKnight, E.B. (2000) Markrecapture study of mountain stone weta Hemideina maori (Orthoptera: Anostostomatidae) on rock tor 'islands'. New Zeal. J. Ecol. 24, 209-214

Junqueira, C.N., Hogendoorn, K., Augusto, S.C. (2012) The use of trap-nests to manage carpenter bees (Hymenoptera: Apidae: Xylocopini), pollinators of passion fruit (Passifloraceae: Passiflora edulis f. flavicarpa). Ann. Entomol. Soc. Am. 105(6), 884-889

Kavati, R. (1998) Florescimento e frutificação do maracujazeiro amarelo (Passiflora edulis f flavicarpa). In: Ruggiero, C. (ed.) Maracujá do plantio à colheita, pp. $107-129$. Funep, Jaboticabal

Klink, C.A., Moreira, A.G. (2002) Past and current human occupation, and land use. In: Oliveira, P.S., Marquis, R.J. (eds.) The Cerrados of Brazil: ecology and natural history of a neotropical savanna, pp. 69-88. Columbia University Press, Washington

Krebs, C.J. (1989) Ecological methodology. Harper Collins, New York

Kunin, W.E. (1997) Population size and density effects in pollination: pollinator foraging and plant reproductive success in experimental arrays of Brassica kaber. J. Ecol. 85(2), 225-234

Larsson, M., Franzén, M. (2008) Estimating the population size of specialized solitary bees. Ecol. Entomol. 33(2), 232-238

Lettink, M., Armstrong, D.P. (2003) An introduction to using mark-recapture analysis for monitoring threatened species. Dep. Conserv. Tech. Ser. 28A, 5-32

Liberato, J.R., Costa, H. (2001) Doenças fúngicas, bacterianas e fitonematóides. In: Bruckner, C.H., Picanço, M.C. (eds.) Maracujá tecnologia de produção, pós-colheita, agroindústria, mercado, pp. 243-282. Editora Cinco Continentes, Porto Alegre

Melo, G.A.R., Varassin, I.G., Vieira, A.O.S., Menezes, A.O., Löwenberg-Neto, P., et al. (2005) Polinizadores de maracujás no Paraná. Subprojeto 02.02.89. Relatório Técnico. PROBIO Edital 02/2003 - Uso sustentável e restauração da diversidade de polinizadores autóctones na agricultura e nos ecossistemas associados. Curitiba, PR.

Mesquita, T.M.S., Augusto, S.C. (2011) Diversity of trapnesting bees and their natural enemies in the Brazilian savanna. Trop. Zool. 24(2), 127-144

Michener, C.D. (2000) The bees of the world. The John Hopkins University Press, Baltimore 
Myers, N., Mittermeier, R.A., Mittermeier, C.G., Fonseca, G.A.B., Kent, J. (2000) Biodiversity hotspots for conservation priorities. Nature 403, 853-858

National Research Council of the National Academies (2007) Status of Pollinators in North America. National Academies Press, Washington, D.C. http:// books.nap.edu/catalog.php?record_id=11761

Neto, P.L. (2008) Levantamento planimétrico $n^{\circ} 36.243$, Prefeitura de Uberlândia, Minas Gerais

O'Toole, C., Raw, A. (1991) Bees of the world. Blandford, London

Oliveira-Filho, J.H., Freitas, B.M. (2003) Colonização e biologia reprodutiva de mamangavas (Xylocopa frontalis) em um modelo de ninho racional. Cienc. Rural. 33(4), 693-697

Pereira, M., Garófalo, C.A. (2010) Biologia da nidificação de Xylocopa frontalis e Xylocopa grisescens (Hymenoptera, Apidae, Xylocopini) em ninhos-armadilha. Oecol. Aust. 14(1), 193-209

Potts, S.G., Biesmeijer, J.C., Kremen, C., Neumann, P., Schweiger, O., Kunin, W.E. (2010) Global pollinator declines: trends, impacts and drivers. Trends Ecol. Evol. 25(6), 345-353

Ramalho, M., Batista, M.A., Silva, M. (2004) Xylocopa (Monoxylocopa) abbreviata Hurd \& Moure (Hymenoptera: Apidae) e Encholirium spectabile (Bromeliaceae): uma associação estreita no semi-árido do Brasil tropical. Neotropical Entomol. 33(4), 417-425
Rosa, R., Lima, S.C., Assunção, W.L. (1991) Abordagem preliminar das condições climáticas de Uberlândia (MG). Soc. Nat. 3(5-6), 91-108

Roulston, T.H., Goodell, K. (2011) The role of resources and risks in regulating bee populations. Annu. Rev. Entomol. 56, 293-312

Silva, J.R. (2005) A cultura do maracujazeiro (Passiflora edulis Sims. f. flavicarpa Deg.) na Região do Triângulo Mineiro. Aspectos práticos, Relatório técnico

Silveira, F.A., Melo, G.A.R., Almeida, E.A.B. (2002) Abelhas Brasileiras: Sistemática e Identificação. MMA, Fundação Araucária, Belo Horizonte

Siqueira, K.M.M., Kill, L.H.P., Feitosa, C.M., Lemos, I.B., Monteiro, S.P., Feitosa, E.A. (2009) Ecologia da polinização do maracujá-amarelo, na região do vale do submédio São Francisco. Rev. Bras. Frutic. 31(1), 1-12

Steffan-Dewenter, I., Schiele, S. (2004) Nest-site fidelity, body weight and population size of the red mason bee, Osmia rufa (Hymenoptera: Megachilidae), evaluated by markrecapture experiments. Entomol. Gen. 27(2), 123-132

Vaissière, B.E., Freitas, B.M., Gemmil-Heren, B. (2011) Protocol to detect and assess pollination deficits in crops: a handbook for its use. Food and Agriculture Organization of the United Nation, Rome

Yamamoto, M., Silva, C.I., Augusto, S.C., Barbosa, A.A.A., Oliveira, P.E. (2012) The role of bee diversity in pollination and fruit set of yellow passion fruit (Passiflora edulis forma flavicarpa, Passifloraceae) crop in Central Brazil. Apidologie 43(5), 515-526 